\title{
THE EFFECTS OF RELIGIOUSITY, PRICING AND CORPORATE IMAGE ON THE ATTITUDE AND THE INTENTION TO USE SHARIA MICRO FINANCING
}

\author{
Zuliyanti Shabrina $^{* 1}$, Lilik Noor Yuliati**), and Megawati Simanjuntak ${ }^{* *}$ \\ *) School of Business, Bogor Agricultural University \\ SB IPB Building, Pajajaran Road, Bogor 16151 \\ ${ }^{* *}$ Department of Family and Consumet Sciences, Faculty of Human Ecology, Bogor Agricultural University \\ Jl. Lingkar Akademik, Dramaga, Bogor, Indonesia 16680
}

\begin{abstract}
The Developing of Micro, Small and Medium Enterprises (MSMEs) in Indonesia could not be separated from the support of banking system in bank credit disbursement to MSMEs sector. Mandiri Sharia Bank (BSM) is one of the sharia banks that had disbursed sharia micro financing (micro credit). The objective of this research was to analyze the influence of religiosity, pricing and corporate image toward the attitude and the intention to use sharia micro financing. This research, hopefully, could give recommendations of marketing strategies to increase the number of debtors to use sharia micro financing (micro credit). This research used 150 respondents that had been chosen purposively with some criteria, such as entrepreneurs (prospective customers) who have a company in MSMEs sector but they have never experienced using sharia micro financing. The data were analyzed using SEM with SmartPLS3 software. This is a quantitative research using a descriptive approach. The data of respondents were collected by face-to-face interview using a questionnaire tool. The result showed that pricing and corporate image through the attitude provided significant influence on the intention to use sharia micro financing. Meanwhile, the religiosity and corporate image provide insignificant influence on the intention to use sharia micro financing. The fixed pricing and good corporate image would increase the attitude and the intention to use sharia micro financial services.
\end{abstract}

Keywords: MSMEs, SEM, intention to use, pricing, sharia micro financing

\begin{abstract}
Abstrak: Berkembangnya Usaha Mikro, Kecil dan Menengah (UMKM) di Indonesia tidak lepas dari dukungan sistem perbankan dalam penyaluran kredit perbankan ke sektor UMKM. Bank Mandiri Syariah (BSM) adalah salah satu bank syariah yang telah menyalurkan pembiayaan mikro syariah (kredit mikro). Tujuan dari penelitian ini adalah untuk menganalisis pengaruh religiusitas, harga dan citra perusahaan terhadap sikap dan niat untuk menggunakan pembiayaan mikro syariah. Penelitian ini, memberikan rekomendasi strategi pemasaran untuk meningkatkan jumlah debitur untuk menggunakan pembiayaan mikro syariah (kredit mikro). Penelitian ini menggunakan 150 responden yang dipilih secara purposif dengan beberapa kriteria, seperti wirausahawan (calon pelanggan) yang memiliki perusahaan di sektor UMKM tetapi belum pernah menggunakan pembiayaan mikro syariah. Data dianalisis menggunakan SEM dengan perangkat lunak SmartPLS3. Ini adalah penelitian kuantitatif menggunakan pendekatan deskriptif. Hasil penelitian menunjukkan bahwa harga dan citra perusahaan melalui sikap memberikan pengaruh yang signifikan terhadap niat untuk menggunakan pembiayaan mikro syariah. Sementara itu, religiusitas dan citra perusahaan memberikan pengaruh yang tidak signifikan terhadap niat untuk menggunakan pembiayaan mikro syariah. Harga tetap dan citra perusahaan yang baik akan meningkatkan sikap dan niat untuk menggunakan layanan keuangan mikro syariah.
\end{abstract}

Kata kunci: UKM, SEM, niat untuk menggunakan, harga, pembiayaan mikro syariah

\footnotetext{
${ }^{1}$ Corresponding author:

Email: zshabrina.790@gmail.com
} 


\section{INTRODUCTION}

Micro, Medium and Small Enterprises (MSMEs) are one of the important parts of Indonesia's economy and so far this sector is one of the sectors that have survived to face the dynamic Indonesia's economy. MSMEs have relatively big market shares i.e. $20 \%$ and accommodated more than $80 \%$ of the total Indonesia labor force.

There are two types of micro credit that become optional for the entrepreneurs in the MSMSs sector, such as conventional micro credit and sharia micro credit (sharia micro financing). The Difference between conventional micro credit and sharia micro financing is the procedure of credit contract and the installment payment. Conventional micro credit is based on credit contract in which the debtors must pay their debts plus interest, whereas sharia micro credit (sharia micro financing) is based on akad murabahah (credit contract in Islamic term for selling-buying). The Bank acts as a seller of the goods and the debtors act as buyer of the goods (Butt et al. 2011). The Developing of credit in the MSMEs sector around $2012-2016$ could be explained in detail in Table 1.

A person's religiosity is manifested in various aspects of his life (Muhammad et al. 2015). Religious activity not only occurs when a person performs a ritual act, but also when performing other activities that are driven by spiritual power. According to Harisah (2011) religious factor is one of the important motivators to encourage buying interest in sharia bank services. Religiosity exists in various aspects of life including economic and banking institutions, and economic aspects. Banking institutions including the aspects of sharia related to muamalah activities that need to be considered that all allowed except forbidden i.e. usury. The more a person fears punishment from his god, the more they have a good perception of sharia banking (Zahri and Hafasnuddin, 2017).
The pricing system of financing sharia basis and financing conventional basis is different. The fixing price actually affects the customer's intention to use sharia micro financing. According to Ali et al. (2015) and Arifudin (2014), the pricing has significant influence on the intention to use sharia micro financing product. Amin (2012) stated that between pricing and the decision of debtors to use sharia financing products there is an inverse relationship. So, the higher price, the more debtors have the barriers to make decision and to use sharia financing product.

The Corporate image has also an important role to determine the customer's interest to choose what types of credit products that they would need. The Corporate image becomes one of the variables that influence the customer's intention of buying (Putra et al. 2015). The Corporate image has a significant influence to affect the customer's interest and the customer's decision to use sharia financing products (Arifudin, 2014). The Exclusive image, the innovative image and the affordable pricing image towards a corporate become determinant variables to affect the customer's intention of buying (Sutojo, 2004).

The Attitude is one of the factors that could explain about someone's interest to use sharia banking products, such as sharia financing products. It can be conducted through the education and the customer's knowledge about sharia banking. Those marketing activities could also result in the needs of Muslim customers or NonMuslim customers to use sharia banking products (Lestari et al. 2017).

Based on the result of the research above, it is important to know what kinds of reasons will be the background of the customer's interest to use sharia micro financing product and services. Furthermore, the following research about the variables, such as religiosity, pricing and corporate image that could influence the customer's interest would improve the customer's objective to develop their business by using the sharia micro financing enterprise.

Table 1. The Growth of MSMEs Credit 2012-2016

\begin{tabular}{lccccc}
\hline \multicolumn{1}{c}{ Outstanding Balance of } & 2012 & 2013 & 2014 & 2015 & 2016 \\
\hline Micro-Enterprise Credit & $113,754.00$ & $137,797.70$ & $179,748.30$ & $199,123.40$ & $218,511.90$ \\
Small-Enterprise Credit & $169,882.50$ & $193,060.30$ & $224,348.30$ & $239,194.50$ & $266,618.50$ \\
Medium-Enterprise Credit & $268,589.50$ & $308,613.50$ & $363,481.10$ & $392,338.30$ & $415,259.40$ \\
Total MSMEs Credit & $552,226.10$ & $639,471.50$ & $767,577.60$ & $830,656.20$ & $900,389.80$ \\
\hline
\end{tabular}


The Development of MSMEs are in line with the development of micro and small financing that have been disbursed by the fiancial institutions. There are rivaling in growing the disbursement of financing in MSMEs sector that demands a new effective and eficient strategies to improve the customer's interest to use sharia micro financing of Mandiri Sharia Bank (BSM). The marketing becomes used to talking about the basic behavior concept to understand the part of customer's behavior (Putit and Johan, 2013). Therefore, there is information that correlates to the customers, such as important elements to influence their interest

Based on the research questions, the objectives of this research were: To analyze the direct influence of religiosity, pricing and corporate image toward the intention to use micro credit services; To analyze the indirect influence of religiosity, pricing and corporate image through the attitude towards of the intention to use sharia micro financing services; To analyze the influence of the attitude towards the intention to use sharia micro financing services; To formulate the recommendations of the marketing strategies to increase the number of debtors of sharia micro financing.

This research scope used the approach from the customer's perspective to know how big the direct influence and indirect influence of religiosity, pricing and corporate image on the attitude toward the intention to use sharia micro financing. This research was conducted according to the respondent selection criteria, such as the customers of Mandiri Sharia Bank who had an enterprise in MSMEs sector and who had never experienced to use sharia micro financing.

\section{METHODS}

The research was conducted in 10 outlets of micro under the authority of Mandiri Sharia Bank at JakartaPondok Kelapa Area, such as Gandaria Sub-Branch Outlet, Ciracas Sub-Branch Outlet, Cililitan SubBranch Outlet, Cibubur Sub-Branch Outlet, Pondok Gede Branch Outlet, Dewi Sartika Sub-Branch Outlet, Pondok Kelapa Branch Outlet, Pasar Rebo Sub-Branch Outlet and Kemang Pratama Sub-Branch Outlet. This research was held during September - December 2017. This research used the quantitative approach and the survey's method that involved the respondents of banking management level.
This research used the non-probability sampling technique. The type of samples that is used is purposive sampling. This Research used a number of samples, 150 respondents that were qualified to represent the population of debtors. The chosen respondents were customers (prospective debtors) of Sharia Mandiri Bank who had an enterprise in MSMEs sector and they have never experienced to use sharia micro financing. The collected data are primary data. The data collection used in this research was face-to-face interview with a questionnaire tool. Researcher asked respondents to fill in the questionnaire within the closed-ended questions. The deployment of questionnaire began to identify the needs of debtors who would use sharia micro financing for their financial needs. Those samples were collected from 10 outlets under the authority of Mandiri Sharia Bank at Jakarta-Pondok Kelapa Area.

The data collection is primary data. The primary data were collected from the first source, such as the result of paper questionnaire that had been completed by respondents. The primary data stated that the respondents were customers of Mandiri Sharia Bank which had some characteristic such as demography characteristic, owners of an enterprise in MSMEs sector, the intention to use sharia micro financing, religiosity, pricing, corporate image and the attitude. The primary data were collected from the results of the respondents' interview.

Based on the empirical study that had been conducted, it would be presumed that religiosity, pricing, corporate image and attitude could influence the intention to use sharia micro financing. Besides that, the attitude also became an intermediary variable among religiosity, pricing and corporate image to influence the intention to use sharia micro financing. Conceptually, the framework thinking of this research could be seen in Figure 1.

Based on the frame of mind that has been explained above, the hypothesis for the guidance of this research is as follows:
H1 : The Religiosity through the attitude could influence the intention to use significantly
H2 : The Pricing through the attitude could influence the intention to use significantly
H3 : The Corporate Image through the attitude could influence the intention to use significantly 
H4 : The Religiosity could influence the intention to use significantly

H5 : The Pricing could influence the intention to use significantly

H6 : The Corporate Image could influence the intention to use significantly

H7 : The Attitude could influence the intention to use significantly

The processing data in this research has been conducted with some analysis. The analysis that has been conducted is the descriptive analysis that uses SPSS 24 and The Structural Equation Modeling (SEM) with Smart PLS 3. SEM is used to identify the model whether it is in accordance with the actual reality. Excess SEM is able to know the influence of the indicator on the variables. To answer research questions in order to reveal certain social phenomena, data analysis and interpretation are required.

\section{RESULTS}

\section{Respondent Characteristics}

The result of this research showed that from 150 respondents, $60 \%$ of them are men and $40 \%$ are women. The range of age is around 30 to 40 years old that represent $36 \%$ of the total respondents. The education of major respondents is dominated by bachelor degrees which represent $47 \%$ of the total respondents. The marital status of respondents who are married represents $79 \%$ of the total respondents, and then $43 \%$ of the total respondents have a job status as private employees or State Owned Enterprises (SOEs) employees. The range of the respondents' salary per month from their job is below five million rupiah.

\section{MSMEs Profile}

The sector of enterprise the respondents own in MSMEs sector was dominated by food industries segment which was marketed by offline (face-to-face selling basis) or online (via website or social media basis). The result of the research showed that majority of the enterprises that respondents owned in MSMEs sector had gross sales around $<$ Rp5,000,000-10,000,000 (72\% of the total respondents), $37 \%$ of the total respondents started business 1 to 3 years ago, $75 \%$ of the total respondents had never used a bank credit for their capital venture. Meanwhile, so far, $85 \%$ of the total respondents had never used a bank credit for their capital venture from another bank. There are some reasons that become the respondents' consideration for using a bank credit for their capital venture. The respondents' consideration showed that $36 \%$ chose a bank credit because of the lower pricing and faster disbursement process. Those are the respondents' primary considerations for choosing it.

\section{Variable Indicator Description}

Almost all respondents agreed to the indicators about religiosity. It was noted that of the $100 \%$ of the total respondents agreed about 9 out of 12 points that inquire religiosity in the questionnaire. That means that almost all respondents had high religiosity level. Almost 92.7\% of the total respondents agreed that the cost of sharia micro financing from Mandiri Sharia Bank (BSM) is fair. All the respondents agreed that Mandiri Sharia Bank (BSM) had given benefits and secure feeling to its debtors. This indicates that BSM image has been welcome well by the respondents. The majority of respondents (98\%) liked BSM because of its products or its services that are offered to costumers are in accordance with Islamic law (sharia). This made 91.3\% of the total respondents agreed to find some information and ask their friends who had 1-3 month experience to become debtors of BSM sharia micro financing.

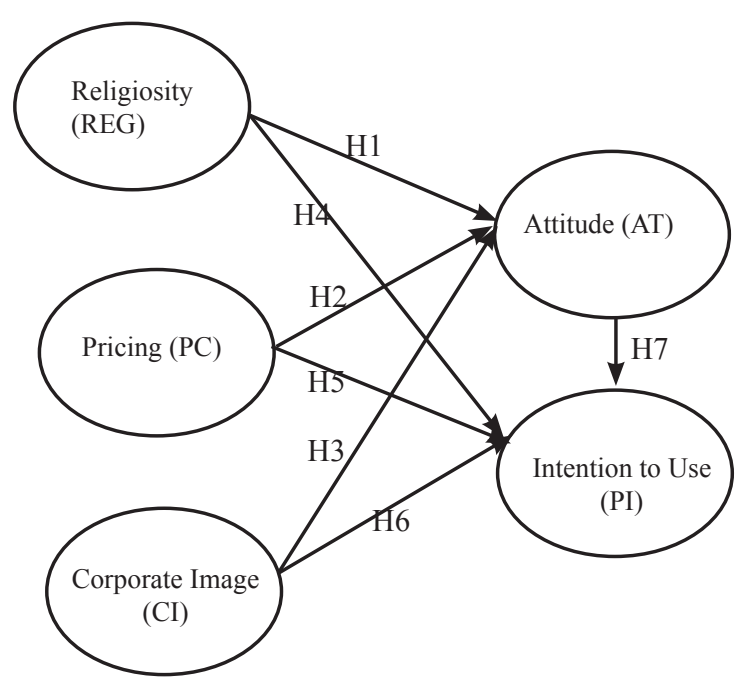

Figure 1. Research framework 


\section{Structural Model Fit Test}

The testing of structural model was conducted with similar coefficients with the structural model that can be specified for the measurement of their significant level. After they were calculated and eliminated with some indicators, the structural model fit became valid enough to calculate the construct of their latent. Figure 2 shows the indicator that has a loading factor score $>0.5$.

\section{Measurement Model Fit Test}

The attributes will become valid if they have a loading factor score $\geq 0.5$, so the indicator variable has a good validity. The next step was testing the validity. The measurement of model fit criteria can be measured based on the validity of indicator variables towards the variable of its latent. Some indicators were said to be valid if they had a loading factor score $\geq 0.5$ and they had the t-score higher than 1.96 (Igbaria et al. 1997).

After they were calculated for several times, they got an indicator scoring that met the requirement of validity and then they could be used for further analysis. Meanwhile, the indicators that haven't met the requirement will be eliminated. From 12 indicators of religiosity, seven indicators could be said to be valid. The pricing variable, the fifth indicator had a valid score. The corporate image, the third indicator could be considered valid, while the fourth indicator was not valid. The attitude variable, the third from five indicators could be said valid. Meanwhile, the variable of the intention to use has three indicators that meet the requirement of validity. In Figure 2 it is shown that the indicator has a loading factor score $>0.5$.

Another method that was used to measure the construct validity was to see the AVE score in every latent variable. The AVE score in every latent variable had the score $>0.5$. This score could meet the requirement (Hair et al. 2006). Based on Table 2, all the construct variables have the AVE score $>0.5$. This shows that the model has validity with a good reflective indicator. Furthermore, one of the variables could be said adequate consistent variable if this variable had the composite reliability score and Cronbach Alpha >0.7. According to Hair et al. (2008) rule of thumb, alpha score or composite reliability must have bigger score than 0.7 , although the score of 0.6 still could be accepted. The results of the research could be seen in Table 2. It shows all latent variables are reliable, accurate and consistent because they meet the requirement with the composite reliability score in every latent variable higher than 0.7 , so the result of this research could be stated valid and reliable.

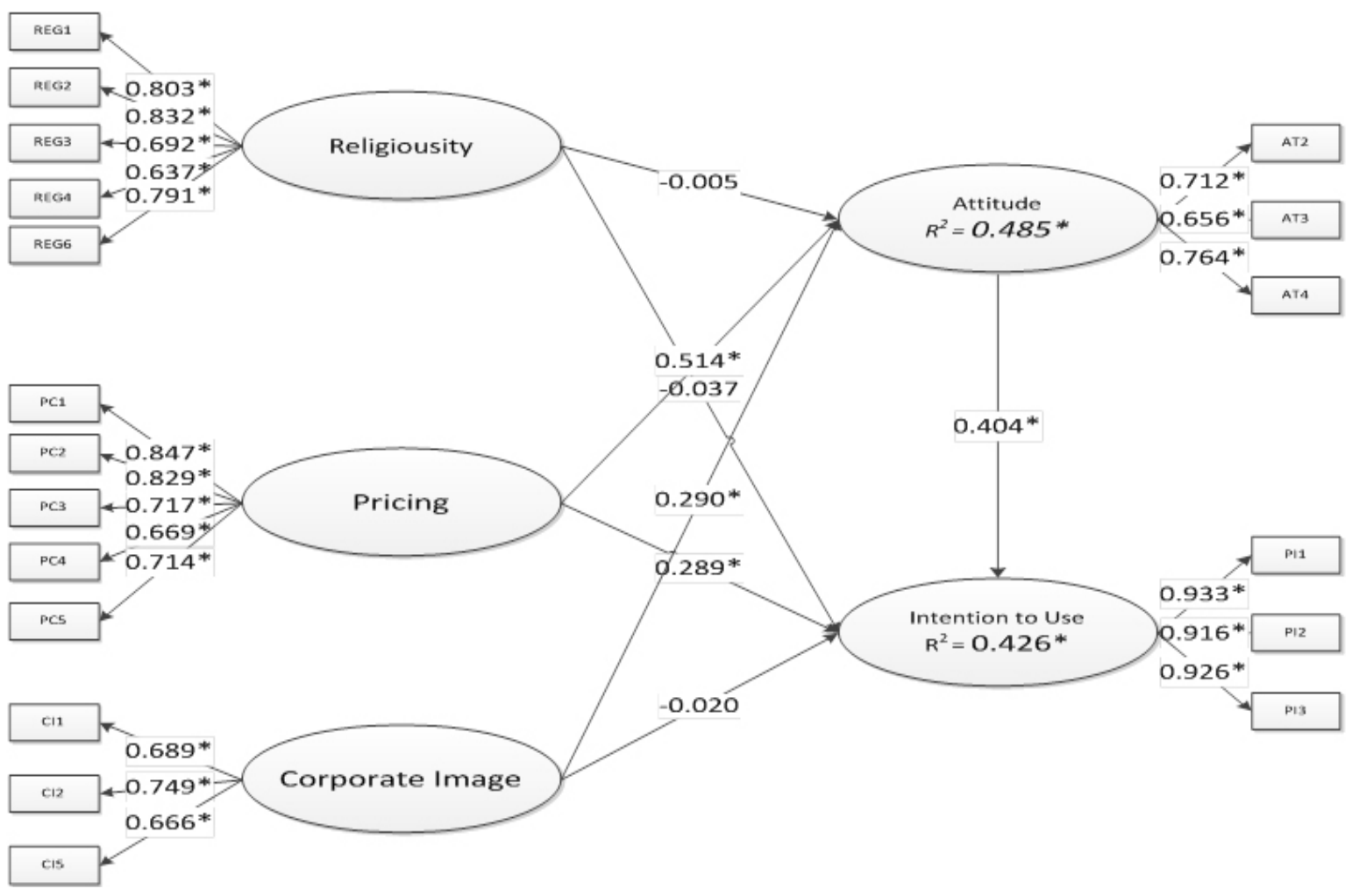

Figure 2. Structural model fit after they are eliminated 
The Structural Model of attitude resulted in R-square score 0.473 , that means the similar attitude could be explained from the model were $47.3 \%$, while the rest $52.7 \%$ could be explained to other factors from the other model. The Structural Model of the intention to use resulted in R-square score 0.382 , which means the similar intention to use could be explained from the model were $38.2 \%$, whereas the rest $61.8 \%$ could be explained from the other model.

\section{Indicator Contribution Towards Religiosity Variable}

The latent variable of religiosity has 12 indicators after some of them have been eliminated. They have 5 indicators with good validity score. The explanation of loading factor and t-score in every religiosity variable would be detailed and presented in Table 3.

Religiosity dimension (REG) consists of five indicators. The indicator that has the highest contribution is REG 2 with a loading factor score 0.902 . The REG1 indicator and REG6 indicator had the contribution score that was almost equal to REG1 indicator, i.e. 0.868. Therefore, it could be stated that REG2, REG1, and REG6 had high contribution scores towards the religiosity latent variable. The values of religiosity became a primary consideration for the customers (prospective debtors) to use sharia micro financing because of that explanation and those in line with their principles that they believe. The use of financing products that suit with Islamic religion principles and law made the customers (prospective debtors) more peaceful and assured to do their business.

\section{Indicator Contribution toward Pricing Variable}

The latent variable consists of five indicators. The explanation of a loading factor and $\mathrm{t}$-score has been presented in Table 4. The PC1 indicator is the highest contribution score with a loading factor score 0.849 . The indicator that has almost equal score to PC1 was PC2 with a loading factor score 0.829 . Whereas the indicator that has a low loading factor score is PC3 with a loading factor score 0.713 . Then the PC4 indicator has a loading factor score 0.668 . This shows that those indicators have not given much contribution to the pricing attribute. Thus, it could be concluded that the fair cost of financing, the mutual benefit for the bank and the debtors and lower the penalty of micro financing are the primary considerations of respondent to decide for using sharia micro financing from Mandiri Sharia Bank. The decision of using sharia micro financing appeared from the intention to use. The intention to use of sharia micro financing appeared from the suitability of product characteristic with the debtor needs. The lower cost that the debtors must pay in sharia micro financing is the primary factor to decide the determination. This is because of the lower cost of sharia micro financing, so the debtors would not feel a burden for the cost if they use sharia micro financing. The explanation of a loading factor and t-score in every pricing variable would be detailed and presented in Table 4.

Table 2. Score AVE, composite reliability, cronbachs alpha and r-square

\begin{tabular}{lcccc}
\hline \multicolumn{1}{c}{ Latent variable } & AVE & Composite reliability & Cronbachs alpha & R-square \\
\hline Attitude & 0.59 & 0.811 & 0.656 & 0.473 \\
Corporate Image & 0.588 & 0.811 & 0.663 & \\
Pricing & 0.575 & 0.87 & 0.813 & 0.382 \\
Intention to use & 0.856 & 0.947 & 0.916 & 0.887 \\
Religiousity & 0.683 & 0.915 & & \\
\hline
\end{tabular}

Table 3. Score loading factor and t-calculate religiosity

\begin{tabular}{llcc}
\hline \multicolumn{1}{c}{ Indicator } & \multicolumn{1}{c}{ Atribute } & Loading factor & t-score \\
\hline REG1 & Religion is an important thing & 0.868 & 4.755 \\
REG2 & Islam makes better life & 0.902 & 5.676 \\
REG3 & Always pray/ wish to Allah SWT & 0.770 & 3.099 \\
REG4 & Muhammad SAW is the main role model & 0.709 & 2.396 \\
REG6 & Believe that Allah SWT always gives us help & 0.868 & 4.205 \\
\hline
\end{tabular}


Table 4. The loading factor score and t-score pricing atribute

\begin{tabular}{|c|c|c|c|c|}
\hline Indicator & Attribute & Loading factor & t-score & R-square \\
\hline $\mathrm{PC} 1$ & The cost from sharia micro financing of BSM is fair & 0.849 & 25,725 & 0.473 \\
\hline $\mathrm{PC} 2$ & $\begin{array}{l}\text { The cost level of sharia micro financing of BSM provides the mutual } \\
\text { benefit for the bank and the debtor }\end{array}$ & 0.829 & 23,490 & \\
\hline PC3 & $\begin{array}{l}\text { The financing cost pricing in the sharia micro financing of BSM is } \\
\text { lower than other sharia banks }\end{array}$ & 0.713 & 12,408 & \\
\hline PC4 & The coverage-colateral level in sharia micro financing is easy & 0.668 & 10,429 & 0.382 \\
\hline PC5 & The penalty of cost pricing in sharia micro financing of BSM is low & 0.717 & 13,913 & \\
\hline
\end{tabular}

\section{Indicator Contribution Towads Corporate Image Variable}

The latent variable of corporate image consits of seven indicators. The detailed explanation about loading factor and t-score on corporate image variable can be seen in Table 5.

The indicator that has the biggest contribution is CI1 indicator with a loading factor score 0.778 . Other two indicators stated in Table 5 that have almost similar score are CI2 indicator with a loading factor score 0.769 and CI5 indicator with a loading factor score 0.753 . The corporate image could influence the intention of someone to use services and products. There is a need to build the customer trust, especially in banking business which is needed to have a good image in public. The BSM indicator that has given benefits to its debtor (CI1) is the highest contribution score that the respondents trust to BSM and then BSM could offer its products or its services easier, especially sharia micro financing of Mandiri Sharia Bank.

\section{Indicator Contribution Towards Attitude Variable}

From the result of calculation proceeded with the PLS that is presented in Table 6, it shows that the attitude indicators have relatively high contribution of the construct with a loading factor score $>0.5$. The AT4 indicator is the highest contribution score with a loading factor score 0.828 , then AT2 has a loading factor score 0.795 and AT3 has a loading factor score 0.672. It can be concluded that the feeling of trust to Mandiri Sharia Bank, transparency of financing cost of the product and the feeling of proud to use products or services of BSM as the biggest sharia bank by asset in Indonesia are the indicators that influence the respondents to determine the decision to use sharia micro financing.

\section{Indicator Contribution Toward the Intention to Use Variable}

The PL1 indicator has the highest contribution score to the construct with loading factor score 0.933 . The influence that has not much different score is seen from the PI3 indicator with a loading factor score 0.926 . All three indicators of the intention to use provide the influence to the construct including the PI2 indicator with a loading factor score 0.916 . Based on the result of the measurement, it can be concluded that all the indicators provide relatively high influence score on the intention to use variable. The explanation of the loading factor and t-score in every intention to use variable would be detailed and presented in Table 7 .

\section{Hypothesis Testing}

The result of hypothesis shows that religiosity variable has an insignificant influence directly and indirectly. This indicates that religiosity of a loading factor score toward the intention to use, -0.037 , and then when it is used through the attitude, the score becomes -0.005 . The result that supports this research has been conducted differently by Ali et al. (2015) and Amin et al. (2011). Their research resulted that religiosity impacts negatively and insignificantly to form the intention to use. The religious values enable to influence the intention to use if someone has the highest religiosity level. In this research, the respondents made that the religious factors have not become the determinant factor for using sharia micro financing. The corporate image variable influences insignificantly (t-score $=$ 0.883 ) in the intention to use. This analysis is contrary with the research that has been conducted by Putra et al. (2015) and Arifudin (2014). Their research stated that corporate image was the factor that had positive and significant determinant to form the intention to use. The direct influence of the intention to use resulted from the pricing variable with a loading factor score 0.289 . The attitude variable also had a significant influence 
$(\mathrm{t}$-score $=4.448)$ towards the intention to use with a loading factor score 0.404 . In other words, to increase the intention to use a corporate product or service, it must do several efforts to increase the attracted attitude to the customer for the fixed price. It is expected that it would create the goodwill from customers to use sharia micro financing of BSM. The research of Makmun and Ratnasari (2015), Kane (2007), Bawono (2011), Amin (2012) and Munthe (2014) also showed that the pricing variable has a positive and significant influence to form the intention to use.

The indirect influence of the intention to use could be obtained from the pricing through the attitude which had a loading factor score 0.514 . The enforcement of the financing fair cost that had been managed transparently was intended to make the debtors get easier access for the installment payment. The system of installment payment and the financing cost must be formulated well by a bank, so the bank and the debtors would get mutual benefit. Unlike the direct influence, the corporate image through the attitude had a significant influence $(\mathrm{t}$-score $=4.038$ ) on the intention to use with a loading factor score 0.290 . This showed that the good pricing that was suited with the debtors' needs and that could build the good corporate image would influence to the next of the attitude, and thus it would impact on the customer to use sharia micro financing of BSM. This analysis is supported by the research that had been conducted before by Amin (2012), Ali and Athambawa (2013) and then Lajuni et al. (2017). In their research it was stated that the attitude influenced the intention to use significantly. The estimated result of SEM model would be detailed and presented in Table 8 .

The respondents were chosen in one of the areas, so they couldn't be generalized to represent the nationwide population. The analysis is general for sharia micro financing industry, so the marketing strategies implementation could be applied differently from one to another.

Table 5. The loading factor score and t-score on corporate image attribute

\begin{tabular}{|c|c|c|c|}
\hline Indicator & Attribute & Loading factor & t-score \\
\hline CI1 & BSM has given benefits to its debtors & 0.778 & 13,493 \\
\hline $\mathrm{CI} 2$ & BSM has given the secure feeling & 0.769 & 10,449 \\
\hline CI5 & BSM has given the proud feeling as the biggest sharia bank by asset in Indonesia & 0.753 & 11,259 \\
\hline
\end{tabular}

Table 6 . The loading factor score and t-score on attitude attribute

\begin{tabular}{llrc}
\hline Indicator & & Loading factor & t-score \\
\hline AT2 & $\begin{array}{l}\text { Being happy to use capital venture financing product of BSM because of the } \\
\text { transparency of financing cost }\end{array}$ & 0.795 & 19,993 \\
AT3 & $\begin{array}{l}\text { Being proud to use a product or a service of BSM because BSM is the biggest } \\
\text { sharia bank by asset in Indonesia }\end{array}$ & 0.672 & 8,912 \\
AT4 & Trusting BSM for developing my enterprise & 0.828 & 26,925 \\
\hline
\end{tabular}

Table 7. The loading factor score and t-score on the intention to use attribute.

\begin{tabular}{llrc}
\hline Indicator & & Loading factor & t-score \\
\hline PI1 & $\begin{array}{l}\text { Intending to find the information about sharia micro financing of BSM for the } \\
\text { next 1-3 months }\end{array}$ & 0.933 & 58,413 \\
PI2 & $\begin{array}{l}\text { Intending to become the debtor of sharia micro financing of BSM for the next 1-3 } \\
\text { months }\end{array}$ & 0.916 & 39,636 \\
& $\begin{array}{l}\text { Willing to ask a friend that has become a debtor of sharia micro financing about } \\
\text { the financing product }\end{array}$ & 0.926 & 61,110 \\
& &
\end{tabular}




\begin{tabular}{|c|c|c|c|c|c|c|}
\hline & Influence Variable & Path coefficient & T-score & R-square & Conclusion & Information \\
\hline H1 & Religiosity $\rightarrow$ Attitude $\rightarrow$ Intention to use & -0.005 & 0.144 & & $\begin{array}{c}\text { Not } \\
\text { Significant }\end{array}$ & Deny H1 \\
\hline $\mathrm{H} 2$ & Pricing $\rightarrow$ Attitude $\rightarrow$ Intention to use & 0.514 & $9.142 *$ & 0.473 & Significant & Accept H2 \\
\hline H3 & Corporate Image $\rightarrow$ Attitude $\rightarrow$ Intention to use & 0.290 & $4.038^{*}$ & & Significant & Accept H3 \\
\hline H4 & Religiosity $\rightarrow$ Intention to use & -0.037 & 0.883 & & $\begin{array}{c}\text { Not } \\
\text { Significant }\end{array}$ & Deny H4 \\
\hline H5 & Pricing $\rightarrow$ Intention to use & 0.289 & $3.143 *$ & 0.382 & Significant & Accept H5 \\
\hline H6 & Corporate Image $\rightarrow$ Intention to use & -0.020 & 0.411 & & $\begin{array}{c}\text { Not } \\
\text { Significant }\end{array}$ & Deny H6 \\
\hline $\mathrm{H} 7$ & Attitude $\rightarrow$ Intention to use & 0.404 & $4.448^{*}$ & & Significant & Accept H7 \\
\hline
\end{tabular}

\section{Managerial Implications}

The managerial implication that was obtained from this research would be highlighted in Table 9 in the form of segmentation, targeting and positioning (STP). Those are used by a corporate as the source of the information and the consideration to make the marketing strategies for the sharia micro financing of Mandiri Sharia Bank that could increase the number of debtors and to increase the outstanding balance of bank as the corporate target.

The segmentation of sharia micro financing product of BSM is the adult group who have been married, have middle to lower income and have a job with permanent status. They could make the considerations of the corporate to do marketing in a form through the activities and behavior of the customers. One of them is do marketing in a form of the education presentation about the importance to have another income beside the salary and then this could be interspersed by presented the product value of sharia micro financing of BSM.

The targeting customers of sharia micro financing of BSM are those who have an enterprise in MSMEs sector that have started their business within 1-3 years. During those periods of their business in MSMEs sector, they would need to gain their capital to expand their business. So, the Sharia micro financing product exists to give the solution to gain their capital venture. The positioning of sharia micro financing of BSM is micro financing that based on the Sharia (the Islamic law). This financing product has some competitors in the similar product, so this product has to adapt itself to the behaviors of the customers. Hopefully, this product could be a market leader of sharia financing product. Therefore, it is important to develop an innovation, so this product could be fitted to the customers' needs, such as the disbursement process that could be conducted in a short time. The use of IT is urgently needed, for example, in part start to apply the financing with IT based and in another verify the collateral with IT based, so the customers do not need to come to the bank several times.

\section{CONCLUSIONS AND RECOMMENDATIONS}

\section{Conclusions}

The pricing and the corporate image have a positive and significant influence through the attitude. The higherlower pricing in the cost of sharia micro financing will determine the customers' attitude in the intention to use the product. The Good corporate image of the company will increase the customer's trust attitude to the company and the sharia micro finacning sercvices of BSM.

The pricing and the attitude could influence dircetly and significantly to the intention to use. The pricing is a primary reason for respondent's consideration to decide the intention to use sharia micro financing of BSM. The attitude showed by respondents, after they got detailed infomation about sharia micro financing, will influence directly and significantly to the intention to use. The higher the attitude, the higher the respondents' intention to choose the sharia micro financing of BSM.

\section{Recommendations}

In reaching the target of outstanding balance of sharia micro financing, the corporate needs to pay attention significantly to the factors that have significant influence on the intention to use, such as, pricing, corporate image and attitude. The next research could include other variables that are related in the intention to use 
that do not exist in this the model. Add other variables that probably influence the intention to use, such as social influence, subjective norm and government support. This research was held at the outlets under the authority of BSM at Jakarta-Pondok Kelapa Area; therefore, hopefully the next research will be held in another area, such as Mandiri Sharia Bank.

\section{REFERENCES}

Ali MSI, Athambawa S. 2013. Determinants of customers' intention to use islamic financing services-The Case of Islamic Bank in Sri Lanka. Proceedings of the SecondARC: Sri Lanka, 2013. Sri Lanka: Institute of Advance Technological Education.

Ali M, Raza SA, Puah CH. 2015. Factors affecting intention to use islamic personal financing in Pakistan: evidence from the modified TRA model. Munich Personal RePEc Archive 66023.

Amin H, Abdul RAR, Stephen LSJ, Ang MCH. 2011. Determinants of customer's intention to use Islamic personal financing: the case of Malaysian Islamic banks. Journal of Islamic Accounting and Business Research 2(1): 22-42.

Amin H. 2012. Determinants of customer's intention to use Islamic personal financing. Journal of Islamic Marketing 4(3): 245-263.

Arifuddin RARA. 2014. A study on determinants of customer's intention to use i-Aslah [tesis].Kedah Darul Aman: Universiti Utara Malaysia.

Bawono A. 2011. Religiosity contribution in behavior of taking interest's consumption. STAIN Salatiga Journal 2(1): 115-134.

Buut I, Nausherwan S, Hassan A. 2011. Barriers to adoption of islamic banking in Pakistan. Journal of Islamic Marketing 2(3): 259-273.

Hair J, Bill B, Bary JB, Rudolph AE, Rudolp LT. 2006. Multivariate Data Analysis. Ed ke-6. New Jersey: Pearson Prentice Hall.

Harisah NA. 2011. Determinants of customer's intention to use islamic personal financing [tesis].Kedah Darul Aman: Universiti Utara Malaysia.
Igbaria M, Zinatelli N, Cragg P, Cavaye LM. 1997. Personal computing acceptance factor in a small firm: a structural equation model. MIS Quarterly 21(3): 279-302.

Kane KF. 2007. The effect of pricing strategy on customer behavior in the personal insurance industry [tesis]. USA: University of Phoenix.

Lajuni N, Winnie PMW, Yuzman Y, Hiram T, Alfera J. 2017. Intention to use islamic banking products and its determinants. International Journal of Economic and Financial Issues 7(1): 329-333.

Lestari BA, Suharjo B, Muflikhati I. 2013. Minat kepemilikan kartu kredit (studi kasus Kota Bogor). Jurnal Aplikasi Bisnis dan Manajemen 3(1): 143-151. http://dx.doi.org/10.17358/ jabm.3.1.143.

Makmun S, Ratnasari TR. 2015. Faktor nasabah memilih BMT Mandiri Sejahtera Gresik. Jurnal Ekonomi Syariah Teori dan Terapan 2(8): 614626.

Muhammad A, Raza SA, Puah CH. 2015. Factor affecting intention to use islamic personal financing in Pakistan: evidence from the modified TRA model. Munich Personal RePEc Archive. MPRA Paper 66023.

Munthe S. 2014. The factors that affect the customer to save in mudharabah savings at Muamalat Bank outlet balai kota [tesis]. Medan: IAIN Sumatera Utara.

Putit L, Johan ZJ. 2013. Consumer's aceptance of halal credit card services: an empirical analysis. Journal of Emerging Economies and Islamic Research 1(1): 1-9.

Putra GBS, Kumadji S, Hidayat K. 2015. The influence of the corporate image toward the intention to visit and the decision to visit. Journal of Business Administration 2: 1-8

Sutojo S. 2004. Built The Corporate Image. Jakarta: Damar Mulia.

Zahri Y, Hafasnuddin. 2017. The influence of religiosity towards the intention to buy a product/service of sharia bank with the consumer's attitude as intermediary variable. Management Collage Scientific Journal 2(1): 118-133. 